\title{
POLA KOMUNIKASI IBU DENGAN ANAK PEREMPUAN SUKU JAWA DALAM PEMILIHAN PASANGAN HIDUP (STUDI KASUS PADA DESA GEMPOL, KECAMATAN REJOSO, KABUPATEN NGANJUK)
}

\author{
Alfien Baddrin Afdhilla dan Syifa Syarifah Alamiyah \\ Program Studi Ilmu Komunikasi, Fakultas Ilmu Sosial dan Ilmu Politik, Universitas \\ Pembangunan Nasional Veteran Jawa Timur, Indonesia \\ Email: alfienba@gmail.com dan Syifa_syarifah.ilkom@upnjatim.ac.id
}

\begin{abstract}
Mother daughter communication must be built harmoniously. This is because the Javanese mother has a big role in the choice of a child's life partner. If the communication that is built is not harmonious, conflicts can occur. In the case study of Gempol Village, this village has its own habits in choosing a life partner, from Javanese customs to village myths. The study was conducted to describe the communication patterns of Javanese mothers and daughters in choosing a life partner. The research method used is descriptive qualitative. The data in this study were collected by means of in-depth interviews which were processed using Braumrind's theory of communication patterns, as well as the dialogical theory of relationships. The results showed that the communication patterns used in the mother and daughter pair in the village of Gempol could prove that they could persuade and maintain the habits of the village of Gempol in choosing a life partner. Three out of five pairs of mothers and children use authoritative (democratic) communication patterns, while the other two are authoritative (authoritarian). The five mothers were proven to impose their will and have high control over their children in choosing a life partner. Mothers try to adapt communication to children with approaches, listening to opinions and using comfortable language. Based on the communication patterns applied and the adjustment efforts, children tend to be obedient or obey the mother's orders, because they think they are more experienced and in order to get blessings.
\end{abstract}

Keywords: communication patterns; mother; daughter; selection of life partner
Abstrak
Komunikasi ibu dengan anak perempuan harus dibangun secara harmonis. Dikarenakan pada Suku Jawa ibu memiliki andil besar dalam pemilihan pasangan hidup anak. Apabila komunikasi yang dibangun tidak harmonis, konflik dapat terjadi. Pada studi kasus Desa Gempol, desa ini memiliki kebiasan tersendiri dalam memilih pasangan hidup, mulai kebiasaan menurut Suku Jawa hingga mitos desa. Penelitian dilakukan untuk mendeskrispsikan pola komunikasi ibu dan anak perempuan Suku Jawa dalam pemilihan pasangan hidup. Metode penelitian yang digunakan adalah kualitatif deskripif. Data dalam penelitian ini dikumpulkan dengan wawancara mendalam yang diolah dengan menggunakan teori pola

$\begin{array}{ll}\text { How to cite: } & \text { Alfien Baddrin Afdhilla dan Syifa Syarifah Alamiyah (2021) Pola Komunikasi Ibu dengan Anak } \\ & \text { Perempuan Suku Jawa dalam Pemilihan Pasangan Hidup (Studi Kasus Pada Desa Gempol, Kecamatan } \\ & \text { Rejoso, Kabupaten Nganjuk), (6)4. http:// 10.36418/syntax-literate.v6i4.2470 } \\ \text { E-ISSN: } & 2548-1398 \\ \text { Published by: } & \text { Ridwan Institute }\end{array}$


komunikasi menurut Braumrind, serta teori dialogis hubungan. Hasil penelitian menunjukkan bahwa pola komunikasi yang digunakan pada pasangan ibu dan anak perempuan di Desa Gempol, dapat membuktikan dapat mempersuasi dan mempertahankan kebiasaan Desa Gempol dalam pemilihan pasangan hidup. Tiga dari lima pasang ibu dan anak menggunakan pola komunikasi Authoritative (demokratis), sedangkan dua lainnya Authoritatian (otoriter). Kelima ibu terbukti memaksakan kehendak dan memiliki kontrol tinggi kepada anak dalam pemilihan pasangan hidup. Ibu berupaya menyesuaikan komunikasi kepada anak dengan pendekatan, mendengarkan pendapat dan menggunakan bahasa yang nyaman. Berdasarkan pola komunikasi yang diterapkan dan upaya penyesuaian tersebut anak cenderung memiliki sifat manut atau menuruti perintah ibu, karena menganggap lebih berpengalaman dan demi mendapatkan restu.

Kata Kunci: pola komunikasi; ibu; anak perempuan; pemilihan pasangan hidup

\section{Pendahuluan}

Secara psikologis, hubungan ibu dengan anak sangat dekat karena sentuhan kasih sayang ibu dapat meredakan tangisan anak dan kesakitan seorang anak merupakan derita seorang ibu (Suciati, 2015). Hubungan antara ibu dan anak cenderung dekat bahkan ibu dianggap sebagai teman pertama seorang anak. Apalagi seorang anak perempuan, mereka memiliki kedekatan yang lebih dengan ibu dibandingkan dengan anak laki-laki. Kedekatan antara anak perempuan dengan ibu diantaranya berkaitan dengan ibu adalah seorang yang selalu menjadi tempat mencurahkan isi hati mereka, menjadi tempat bertukar cerita tentang berbagai hal mulai dari hal yang menyenangkan, menyedihkan bahkan memalukan sekalipun. Bahkan dalam hal pemilihan pasangan bagi seorang anak perempuan, ibu juga menjadi orang yang diajak diskusi, dan pada sebagian anak, ibu menjadi kunci dalam pemilihan pasangan hidup mereka.

Pemilihan pasangan hidup ini terjadi pada anak usia dewasa awal. Usia dewasa awal menurut Erikson dalam (Saraswati, 2011), berkisar antara 20 sampai 30 tahun. Pada masa ini individu memiliki beberapa tugas perkembangan salah satunya yakni memilih pasangan untuk menikah. Meskipun seorang anak sudah dewasa, namun peran seorang ibu masih dibutuhkan seorang anak. Ibu perlu memperhatikan dengan siapa sang anak bergaul, dengan siapa anak berpasangan, dan lingkungan pertemanan anak.

Memilih pasangan hidup merupakan langkah penting yang harus dipertimbangkan secara matang. Karena kesalahan dalam pemilihan pasangan hidup akan berdampak buruk pada kualitas hidup kita di masa depan. Dalam pemilihan pasangan hidup, pada masyarakat tertentu mereka memiliki kriteria tertentu pula yang berbeda dengan masyarakat lainnya. Misalnya pada masyarakat suku Jawa kriteria dalam memilih pasangan hidup berpatokan pada konsep bibit, bebet, bobot calon pasangannya (Lastarya, 2018). Selain melihat konsep tersebut, pada zaman yang modern ini masih terdapat masyarakat yang menganut mitos-mitos pemilihan pasangan hidup yang sebenarnya hal itu dialandasi oleh pemikiran primitif seperti pada salah satu desa di Kabupaten Nganjuk yakni Desa Gempol. 
Desa Gempol merupakan salah satu desa yang terletak di wilayah paling selatan Kecamatan Rejoso Kabupaten Nganjuk. Desa ini dihuni oleh masyarakat dengan latar belakang suku Jawa. Sejarah singkat asal mula desa ini diawali dengan babat alas (hutan) yang terletak di selatan Sungai Widas yang dipelopori oleh Mbah Dipo tahun 1784 (Kominfo Nganjuk, 2019). Desa Gempol memiliki tingkat pendidikan yang masih rendah, dengan tingkat pendidikan terakhir paling banyak adalah tingkat Sekolah Dasar dengan total 676 orang (Negara, 2016). Mayoritas pekerjaan di desa ini adalah sebagai buruh tani dan petani. Namun, yang lebih mendominasi adalah buruh tani yakni sebagai pekerja di lahan sawah milik orang lain. Penduduk desa ini mempertahankan budaya suku Jawa dengan sangat kuat.

Desa ini memiliki masyarakat yang masih percaya mitos dan cenderung pada masyarakat yang masih bersifat tradisional. Menurut Cremers dalam (Anggriancy, 2019) mitos adalah suatu bentuk simbolik yang suci yang menceritakan peristiwa nyata dan imajiner tentang asal usul alam dan kodrati manusia. Mitos mengenai pemilihan pasangan di Desa Gempol masih menganut pula mitos-mitos suku Jawa, namun ada yang berbeda karena berdasarkan pada mitos leluhur desa. Adapun contoh-contoh istilah mitos larangan pemilihan pasangan di Desa Gempol yakni Jilu, Itungan Weton, Tiba Rampas, Jejer Wuwung, Seduluran Wedok Menikah dengan Laki-laki dari satu Desa, Gempol Begadung. Diantara mitos-mitos tersebut, mitos yang paling terkenal dan berbeda dari desa lainnya adalah mitos larangan pemilihan pasangan atau perjodohan dengan warga Desa Begadung.

Masyarakat Desa Gempol percaya jika melanggar mitos ini, akan terjadi musibah berupa kematian atau kebangkrutan yang dialami oleh anggota keluarga. Tidak hanya musibah atau sanksi alam, namun juga terdapat sanksi sosial dimana keluarga dari yang melanggar mitos tersebut mendapat cibiran dan cacian masyarakat sekitar. Bedasarkan pengamatan peneliti sebelum melakukan penelitian, terjadi beberapa konflik yang terjadi antara anak dan orang tua ketika masa pemilihan pasangan hidup. Ketika seorang anak sudah memiliki pasangan (pacar) tetapi tidak sesuai dengan kriteria orang tua bahkan melanggar mitos larangan desa, maka konflik pun terjadi. Konflik ini dapat berdampak buruk pada keharmonisan hubungan orang tua dan anak. Jika hal ini terjadi maka keterbukaan dan kepercayaan anak terhadap orang tua dapat luntur.

Dari beberapa hasil penelitian mengenai banyaknya konflik antara orang tua dengan anak dan adanya mitos yang turun temurun dipercayai dari generasi tua hingga muda mengenai pemilihan pasangan hidup, menunjukkan bahwa komunikasi sangat berperan penting dalam menjelaskan segala sesuatu. Tujuan komunikasi juga menjadi landasan dalam mendidik anak, karena tujuan utama komunikasi adalah persuasi, dimana upaya pembicara untuk menggiring orang lain masuk ke dalam sudut pandang persuader (Liliweri, 2015). Penelitian ini membahas permasalahan bagaimana pola komunikasi yang dibangun dalam hubungan ibu dengan anak perempuan suku Jawa, yang mengambil studi kasus di Desa Gempol dalam proses pemilihan pasangan hidup. Hal ini didasarkan terdapat beberapa mitos-mitos pemilihan pasangan hidup yang masih dipercaya higga sekarang. 
Aktivitas kita sehari-hari merupakan aktivitas komuikasi, terutama komunikasi antar pribadi. Komunikasi antar pribadi umumnya berlangsung secara tatap muka (face to face), komunikasi yang efektif ditandai dengan hubungan interpersonal yang baik pula (Sumardijati, 2012). Pentingnya suatu komunikasi antar pribadi ialah karena proses yang terjadi memungkinkan berlangsung secara dialogis. Dialog adalah bentuk komunikasi antar pribadi yang menunjukkan terjadinya interaksi.

Mereka yang terlibat dalam komunikasi bentuk ini berfungsi ganda, masingmasing menjadi komunikan dan komunikator secara bergantian. Dalam proses komunikasi dialogis nampak adanya upaya dari para pelaku komunikasi untuk terjadinya pergantian bersama (mutual understanding) dan empati, dari proses ini maka terjadi rasa saling menghormati. Komunikasi adalah wadah dalam hubungan komunikasi antar pribadi dalam keluarga yang dilakukan anggota keluarga. Adapun bentuk-bentuk dari komunikasi keluarga dalam (Palianrungi, 2018) salah satunya ialah, komunikasi orang tua dan anak. Komunikasi yang terjalin antara orang tua dan anak dalam satu ikatan keluarga dimana orang tua bertanggung jawab dalam mendidik anaknya.

Pola komunikasi didefinisikan sebagai pola antara dua orang atau lebih dalam pengiriman dan penerimaan pesan dengan cara yang tepat sehigga pesan yang dimaksud dapat dipahami (Djamarah, 2004). Dari komunikasi, akan timbul pola, model, bentuk dan juga bagian-bagian kecil yang berkaitan erat dengan proses komunikasi (Ngalimun, 2018). Pola komunikasi dalam keluarga dapat diterapkan dengan bentuk atau pola hubungan antara orang tua dan anak dalam bentuk proses pengiriman dan penerimaan suatu pesan baik secara verbal maupun nonverbal.

Dari banyaknya penelitian yang dilakukan, lebih dari 1000 keluarga di dunia mengatakan bahwa tipe keluarga yang mampu menjalin pola komunikasi dengan baik bersama anak, yaitu berasal dari orang tua yang mengajarkan sharing hal sekecil apapun yang terjadi (Devito, 2007). Keluarga akan menjadi landasan bagi anak untuk menjalani kehidupan nantinya. Hal ini sesuai dengan salah satu fungsi keluarga yaitu sebagai tempat untuk mengembangkan kepribadian, dan menanamkan nilai-nilai sosial, moral, kebudayaan termasuk agama. Proses pendidikan dan sosialisasi ini dilakukan oleh para orang tua, yaitu ibu dan bapak. Proses tersebut dilakukan dengan melalui pola komunikasi dan pola asuh yang baik antara orang tua dengan anak (Candrasari, 2012). Dengan pola komunikasi yang baik maka akan tercipta sebuah pola asuh yang baik pula.

Terdapat tiga pola komunikasi di dalam hubungan orang tua dan anak menurut Braumrind, yaitu (Yusuf, 2001) Authoritarian (Otoriter) dalam pola hubungan ini, sikap acceptance (penerimaan) orang tua rendah, namun kontrolnya tinggi, suka menghukum secara fisik, bersikap mengkomando (mengharuskan/memerintah anak untuk melakukan semua tanpa kompromi), bersikap kaku (keras), cenderung emosional, dan bersikap menolak. Permissive (Membebaskan) dalam hal ini, sikap acceptance orang tua tinggi, namun kontrolnya rendah, memberi kebebasan kepada anak untuk menyatakan dorongan atau keinginannya. Authoritative (Demokratis) dalam hal ini, sikap acceptance dan kontrol orang tua tinggi, bersikap responsif terhadap kebutuhan anak, 
mendorong anak untuk menyatakan pendapat atau pertanyaan, memberi penjelasan tentang dampak perbuatan yang baik dan buruk.

Sebagai ibu yakni orang tua perempuan dari seorang anak. Terdapat peran reproduktif yaitu peran perempuan sebagai nyonya rumah (home maker) yang bertanggung jawab atas kegiatan reproduktif dan pekerjaan domesitik (Juwito \& Alamiah, 2012). Peran ibu dalam (Mardiyana, 2017) dibedakan menjadi tiga tugas penting, yaitu sebagai berikut, ibu yang selalu menyediakan kebutuhan anak-anak, ibu sebagai teladan atau "model" peniruan anak dan ibu sebagai pemberi stimulasi bagi perkembangan anak.

Persetujuan orang tua terhadap pernikahan tetap menjadi kebutuhan utama dan desakan mereka untuk mempunyai suara dalam pemilihan pasangan yang layak dan sesuai sering kali masik menentukan pilihan bagi anak-anak mereka. Bahkan pada akhirnya anak akan tetap selalu bergantung pada restu orang tua kalau mereka mengharapkan eksistensi yang slamet. Hal ini berari membuktikan bahwa eksistensi dan peran orang tua pada suku Jawa memegang pengaruh yang besar terhadap pemilihan calon pasangan hidup pada anaknya, sehingga dapat dikatakan sebelum anak melakukan pemilihan pasangan orang tua terlibat untuk mengarahkan anaknya untuk mendapatkan pasangan yang layak (Endah, 2006).

Keluarga Jawa memiliki adat istiadat serta nilai-nilai dalam mendidik anak mereka, nilai-nilai yang mereka anut diturunkan dari generasi ke generasi agar keturunan mereka menjadi orang Jawa yang memegang teguh adat dan istiadat dari kebudayaan Jawa itu sendiri, serta yang menjadi identitas diri bagi orang Jawa. Dalam memilih pasangan, orang tua pada keluarga Jawa ikut memilihkan kriteria untuk anaknya. Kriteria tersebut meliputi, bibit, bebet, dan bobot, perhitungan weton, arah rumah, dan mitos desa.

Berikut ini merupakan penelitian terdahulu yang dijadikan bahan referensi oleh penulis, (Dyantika, Wibowo, \& Ayodya, 2018) dengan judul "Pola Komunikasi Antara Orang Tua dan Anak Perempuan Anggota Club Motor CBR di Mojokerto", (Panorama, 2019) dengan judul penelitian "Pola Komunikasi Ibu Dengan Anak Remaja Putri Untuk Mengatasi Perilaku Merokok Di Surabaya”, dan (Hellen Gabrellia Santoso, 2017) dengan judul penelitian "Pola Komunikasi Orang Tua Dalam Mendidik Anak di Keluarga Tionghoa (Studi Kasus Pada Keluarga Tionghoa di Kecamatan Tambora)”.

Terdapat beberapa perbedaan diantara penelitian terdahulu dengan penelitian yang akan penulis laksanakan. Penelitian yang akan dilakukan memiliki pembahasan yang berbeda dari penelitian yang terdahulu yakni mengenai pemilihan pasangan hidup. Meskipun terdapat penelitian terdahulu yang meneliti mengenai pola komunikasi ibu dengan anak namun objeknya berbeda. Begitu pula dengan penelitian yang akan peneliti lakukan akan membahas mengenai pola komunikasi ibu dengan anak perempuan suku Jawa dalam pemilihan pasangan hidup.

Diharapkan penelitian ini dapat memberikan sumbangan pemikiran bagi pengembangan kajian ilmu komunikasi khususnya dalam bidang perkembangan komunikasi antar pribadi. Bagi ilmu pengetahuan, penelitian ini diharapkan mampu 
memberikan kontribusi berkaitan dengan pola komunikasi antar pribadi yang dapat diterapkan oleh ibu dengan anak perempuan suku Jawa dalam pemilihan pasangan hidup. Penelitian ini diharapkan menambah wawasan dan pengetahuan tentang pola komunikasi dan pemilihan pasangan hidup suku Jawa kepada khalayak luas.

\section{Metode Penelitian}

Penelitian ini menggunakan metode kualitatif deskriptif. Penelitian kualitatif merupakan penelitian yang memanfaatkan wawancara terbuka untuk menelaah dan memahami sikap, pandangan, perasaan, dan perilaku individu atau sekelompok orang (Moleong, 2014). Penelitian deskriptif kualitatif ditujukan untuk mendeskripsikan dan menggambarkan fenomena-fenomena yang ada, baik bersifat alamiah maupun rekayasa manusia, yang lebih memperhatikan mengenai karakteristik, kualitas keterkaitan antar kegiatan (Sukmadinata, 2016). Menurut peneliti, dengan digunankannya jenis penelitian deskriptif, hasil yang didapatkan akan lebih jelas menggambarkan pola komunikasi ibu dengan anak perempuan suku Jawa dalam pemilihan pasangan hidup.

Subjek dari penelitian ini yaitu pola komunikasi ibu dengan anak perempuan dewasa awal suku Jawa dalam pemilihan pasangan hidup. Informan ini tidak ditentukan berapa jumlahnya, tetapi dipilih beberapa informan yaitu orang-orang yang dianggap telah mengetahui serta mengikuti perkembangan yang terjadi sesuai substansi penelitian. Peneliti memilih lima pasang informan yang dijadikan sebagai narasumber penelitian. Adapun informan yang akan diwawancarai pada penelitian ini juga harus memenuhi kriteria sebagai berikut:

1. Ibu sebagai informan utama, baik ibu bekerja maupun ibu rumah tangga,

2. Ibu yang memiliki anak perempuan dewasa berusia 20-30 tahun,

3. Ibu dan anak perempuan yang mengerti adat istiadat suku Jawa secara baik terutama mengenai pemilihan pasangan hidup,

4. Anak perempuan dewasa berusia 20 sampai 30 tahun yang sedang menjalin hubungan intim atau berpacaran sebagai informan pendukung untuk melengkapi data penelitian,

5. Lahir dan dibesarkan di Desa Gempol, Kecamatan Rejoso, Kabupaten Nganjuk.

Data primer dalam penelitian ini adalah menggunakan wawancara mendalam (indepth interview). Teknik pengumpulam data sekunder pada penelitian ini yakni dengan studi literatur. Peneliti akan menggunakan teknik analisis data bersifat deskriptif yang diperoleh berdasarkan pola komunikasi keluarga serta mengkaji sesuai dengan konsep pola komunikasi antara ibu dengan anak perempuan dewasa awal suku Jawa dalam memilih pasangan hidup.

\section{Hasil dan Pembahasan}

\section{A. Hasil}

Penelitian pola komunikasi dalam hal ini adalah ibu yang memiliki anak perempuan dewasa awal berusia 20-30 tahun dengan latar belakang Suku Jawa dan sedang dalam proses pemilihan pasangan hidup. Suku Jawa memiliki adat dan 
kebiasaan tersendiri dalam pemilihan pasangan hidup, dalam hal ini orang tua memiliki peran untuk menjelaskan dengan baik kepada anak mereka. Pada usia dewasa awal dipandang sebagai periode yang penting daripada periode lain karena pada usia ini adalah usia dengan tugas perkembangan yang baru. Pada usia dewasa awal juga merupakan masa peralihan dari remaja yang kehidupannya semakin kompleks dengan tanggung jawab baru yang penting dalam kehidupan seseorang. Oleh karena itu, pada masa ini merupakan masa-masa awal yang penting untuk merangkai masa depan khususnya pada pemilihan pasangan hidup.

Pemilihan pasangan hidup dalam penelitian ini berfokus pada studi kasus Desa Gempol, Kecamatan Rejoso, Kabupaten Nganjuk. Pada Desa Gempol sendiri terdapat kebiasaan yang berbeda dengan daerah lainnya yakni larangan memilih pasangan hidup dengan desa tetangga yakni Desa Begadung. Penelitian ini menjadikan informan ibu sebagai informan utama dan anak perempuan dewasa awal sebagai informan pendukung, karena peneliti ingin melihat pola komunikasi yang diterapkan ibu kepada anaknya dalam pemilihan pasangan hidup. Adapun identitas informan yang diwawancarai pada penelitian ini sebagai berikut:

Tabel 1

Data Informan Ibu Desa Gempol

\begin{tabular}{llll}
\hline $\begin{array}{c}\text { No. } \\
\text { Informan }\end{array}$ & Informan & \multicolumn{1}{c}{ Usia } & Pekerjaan \\
\hline 1 & Ibu M & 53 Tahun & Ibu Rumah Tangga dan Bertani \\
\hline 3 & Ibu S & 55 Tahun & Ibu Rumah Tangga \\
\hline 5 & Ibu J & 45 Tahun & Ibu Rumah Tangga \\
\hline 7 & Ibu SS & 54 Tahun & Ibu Rumah Tangga \\
\hline 9 & Ibu SR & 44 Tahun & Ibu Rumah Tangga \\
\hline
\end{tabular}

Sumber: Diolah peneliti berdasarkan wawancara dengan ibu di Desa Gempol

Tabel 2

Data Informan Anak Perempuan Dewasa Awal Desa Gempol

\begin{tabular}{lllll}
\hline $\begin{array}{c}\text { No. } \\
\text { Informan }\end{array}$ & Informan & \multicolumn{1}{c}{ Usia } & \multicolumn{1}{c}{ Status } & \multicolumn{1}{c}{ Pekerjaan } \\
\hline 2 & R & 25 Tahun & Belum Menikah & Karyawan Bank \\
\hline 4 & FRA & 20 Tahun & Belum Menikah & Menganggur \\
\hline 6 & BA & 22 Tahun & Belum Menikah & Mahasiswi \\
\hline 8 & DT & 22 Tahun & Belum Menikah & Mahasiswi \\
\hline 10 & RA & 23 Tahun & Belum Menikah & Karyawatn Cafe \\
\hline
\end{tabular}

Sumber: Diolah peneliti berdasarkan wawancara dengan anak perempuan dewasa awal di Desa Gempol

\section{Komunikasi Ibu dan Anak Perempuan Dewasa Awal}

Peneliti akan menjabarkan hasil dan analisis data dari wawancara yang dilakukan peneliti kepada ibu dan anak perempuan dewasa awal. Bagaimana seorang ibu melakukan perannya kepada anak dan bagaimana pola komunikasi yang diterapkan. Kemudian peneliti akan menganalisis kedua hal tersebut dengan Teori Dialogis Hubungan, guna melihat bagaimana pertukaran lisan atau 
tulisan antara ibu dan anak perempuan. Melihat pula perubahan yang dihasilkan dari perintah dan kekacauan yang terjadi dari komunikasi ibu dan anak perempuan dewasa awal.

\section{a) Peran Ibu dalam Hubungan Komunikasi dengan Anak}

Hasil temuan data menunjukkan setiap ibu memiliki cara yang berbeda dalam melakukan perannya. Mulai dari pemenuhan kebutuhan anak, pengawasan yang dilakukan, hingga memperhatikan permasalahan anak. Dalam pemenuhan kebutuhan, terdapat kebutuhan psikis, spiritual dan sosial yang diterapkan ibu. Hal ini juga menyebabkan adanya perbedaan keterbukaan anak dalam hubungan komunikasi dengan ibunya. Namun, hubungan antara ibu dan anak tidak hanya ditentukan oleh peran yang dilakukan, melainkan juga bagaimana pola asuh yang tercipta dari pola komunikasi yang diterapkan.

\section{b) Pola Komunikasi Ibu dan Anak}

Pola komunikasi yang diterapkan berkaitan dengan bentuk proses pengiriman dan penerimaan suatu pesan baik secara verbal maupun nonverbal dalam hubungan ibu dan anak. Pola komunikasi yang digunakan dalam penelitian ini adalah Authoritaritative (Demokratis), Permissive (Membiarkan) dan Authoritarian (Otoriter) milik Braumrind. Menerapkan pola komunikasi yang baik antara ibu dengan anak bukanlah hal yang sepele. Ibu terkadang tidak memperhatikan hal kecil seperti sering memaksakan kehendak kepada anak, tidak mendengarkan pendapat anak dan salah dalam memberikan penghukuman kepada anak. Ketiga hal tersebut akan dijadikan sebagai indikator penunjang dalam melihat pola komunikasi yang diterapkan antara ibu dan anak perempuan dewasa awal. Indikator tersebut dapat dianalisis sebagai berikut:

Kelima informan anak mereka mengkonfirmasi bahwa ibunya memang seringkali memaksakan kehendak. Seperti pernyataan informan FRA sebagai berikut: "iya (memaksakan kehendak) mbak, tapi lihat ke aku juga sesuai sama apa yang aku inginin, tapi selebihnya harus nurut sama ibu”. Ia mengaku ibunya termasuk memaksakan kehendak, namun ibunya juga mendengarkan keinginan dan pendapat anaknya, meskipun pada akhirnya keputusan tetap ada pada tangan ibunya.

Selain itu, tiga ibu yakni M, J, dan SR mengaku mampu mendengarkan pendapat anaknya dengan baik. Hal itu juga mendapat pembenaran dari anak mereka bahwa ibunya mampu mendengarkan pendapat dengan baik. Namun dua ibu lainnya yakni S dan SR mengaku jarang berinteraksi dan anak mereka mengaku pernah mendapat penolakan sehingga merasa enggan untuk terbuka dengan pendapatnya. Hukuman yang diberikan kelima informan sama-sama menggunakan omelan kepada anaknya. Namun satu informan yakni S mengaku pernah menggunakan hukuman fisik. 


\section{c) Teori Dialogis Hubungan}

Pada teori dialogis hubungan, dialog akan membentuk kebiasaan karena dalam setiap interaksi dialogis merupakan sebuah pandangan terhadap setiap kebiasaan setiap pendiri tertentu. Pada teori ini juga melihat tingkat kemampuan reaksi pada orang yang dituju. Dengan kekuatan sentripetal yang menjatuhkan perintah dan sentrifungal yang mengganggu perintah melalui bahasa sebagai media keduanya, kemudian akan menghasilkan memberi makna baru dalam kehidupan. Peneliti melakukan analisis data wawancara dengan lima pasang informan ibu dengan anak dan membagi subbab menjadi empat, yakni pendekatan, cara menjelaskan, bahasa yang digunakan dan bagaimana reaksi keterbukaan ibu dan anak perempuan dewasa awal.

Seorang ibu memiliki caranya masing-masing untuk membangun kedekatan dengan anak agar mampu menjalin komunikasi dengan baik. Salah satunya yakni menganggap anak sebagai teman dan berusaha mengobrol. Informan $\mathrm{M}, \mathrm{J}, \mathrm{SS}$ dan SR memiliki kesamaan dengan menganggap anaknya seperti teman. Mereka berpendapat bahwa dengan cara menganggap anaknya sebagai teman tersebut dapat membangun hubungan dekat yang lebih dan juga memudarkan batasan antara orang tua dan anak. Sedangkan cara yang dilakukan Informan $S$ dalam menjalin hubungan dengan cara berusaha mengobrol.

Setiap ibu memiliki caranya masing-masing untuk menjelaskan hal-hal penting kepada anak perempuannya. Namun penting untuk diingat cara-cara yang dilakukan ini penting untuk diperhatikan karena pada akhirnya dapat menghasilkan perubahan dalam susunan kehidupan sehari-hari. Dalam penelitian ini, peneliti mendapati beberapa cara yang berbeda, yakni dengan melihat watak anak, menjelaskan secara berulang, serta dengan bercerita dan mengobrol.

Pada teori dialogis hubungan, bahasa digunakan sebagai media bagi kekuatan sentripetal yakni pembawa perintah dan kekuatan sentrifungal yakni pengacau pada sebuah percakapan. Bahasa yang digunakan dapat menggambarkan pertentangan antara dua kekuatan tersebut dengan baik. Berdasarkan wawancara yang dilakukan peneliti pada kelima pasang ibu dan anak perempuan dewasa awal, mereka memiliki kesamaan yakni menggunakan bahasa Jawa Ngoko untuk berinteraksi sehari-hari. Meskipun sebenarnya hal ini menentang penggunaan bahasa Jawa yang benar, mereka tetap melakukannya guna mencapai kenyamanan dan kedekatan ibu dan anak.

Reaksi keterbukaan dari hubungan komunikasi yang dibangun ibu dan anak perempuan dalam penelitian ini dapat dibagi dalam dua subbab yakni terbuka dan tertutup. Berdasarkan pendekatan, cara menjelaskan dan bahasa 
yang digunakan informan yang dijelaskan di atas, informan R, BA dan RA memiliki sikap keterbukaan yang cukup tinggi dengan ibunya. Dengan kedekatan dan keterbukaan menjadikan mereka tidak memiliki keengganan untuk saling merespon, menilai dan memulai ucapan dengan ibunya. Sedangkan informan FRA dan DT mengaku bahwa mereka memiliki sikap tertutup terhadap ibunya. Mereka tidak mau mengutarakan apapun yang sedang terjadi. Peneliti menyimpulkan cara ibu membangun hubungan komunikasi yang baik dengan anak mereka pasti akan berbeda-beda, namun untuk menjalin hubungan komunikasi yang terbuka ibu harus berperan aktif dalam mendekati anak.

\section{Komunikasi yang Diterapkan Dalam Pemilihan Pasangan Hidup Suku Jawa}

Pada Desa Gempol kebiasaan yang dilakukan dalam pemilihan pasangan hidup yakni dimulai dengan berasal dari suku yang sama dan memperhatikan bibit, bebet, bobot. Berdasarkan hasil wawancara, kelima pasang informan ibu dan anak menyampaika bibit, bebet, bobot penting untuk dipertimbangkan. Namun infrorman BA menambahkan “...gambarannya kalo saya mementingkan ke pekerjaan pasangan jadi bobotnya gitu,...”, sehingga bobot dianggap lebih penting. Hal tersebut juga disampaikan oleh informan lainnya.

Setelah memperhatikan faktor tersebut, mereka akan mulai memperhitungkan mengenai perhitungan hari kelahiran (weton) berdasarkan hari kelahiran dengan tujuan menghindari Tiba Rampas. Penjelasan perhitungan weton sebagaimana dikatakan informan $\mathrm{M}$ sebagai berikut: "Perhitungan hari ngono wi ngene lo mbak lek wong Jowo I misale rampas kan gak oleh tibo rampas, misale ngene 24 dibagi 3 kan entek nah iku rampas, lek tibone habis niku rampas dan gakoleh..." (Perhitungan hari itu begini mbak kalau orang Jawa itu misalnya rampas itu tidak boleh). Kemudian Informan BA juga menambahkan nasihat ibunya sebagai berikut: “...saya selalu diberi wejangan kalo memiliki pasangan itu harus tau dia lahir hari apa pasarannya apa kayak pon pahing itu nanti kan bisa dihitung...".

Sedangkan arah rumah pada Suku Jawa yakni Jejer Wuwung dan Ngalor Ngidul. Mereka mengatakan jejer wuwung ini adalah suatu mitos suku Jawa yang tidak memperbolehkan pernikahan antara laki-laki dan perempuan yang arah rumahnya sama dalam satu jalur/jalan yang sama dalam satu desa. Kemudian juga tidak boleh melanggar mitos desa yakni Gempol - Gadung. Sesuai kutipan wawancara Informan M menjelaskan bahwa mitos larangan menikah antar desa ini terjadi tidak hanya antara Gempol dan Gadung namun juga dengan desa Getas. Alasan mitos larangan yang ia ketahui adalah karena huruf ketiga tersebut awalanya sama-sama G. Selain itu ia juga mengatakan alasan lainnya yakni karena menyebrangi Sungai Widas. Informan SS mengatakan: "gempol iku semua orange wes percaya gak boleh nikah sama 
orang gadung lek berani nglewati kali widas buat nikah sama orang gadung iku iso mendatangkan bahaya..." Sanksi yang didapat jika melanggar adalah orang tua salah satu pasangan akan kalah atau meninggal.

\section{a) Pandangan Terhadap Pemilihan Pasangan Hidup Suku Jawa}

Berdasarkan hasil wawancara dengan kelima informan ibu, mereka memiliki tingkat kepercayaan yang sama dengan pemilihan pasangan hidup menurut suku Jawa. Tingkat kepercayaan mereka berada pada tingkat percaya tidak percaya yakni sebenarnya masih ada keraguan dengan adanya larangan ataupun sanksi. Tetapi mereka berupaya untuk tetap percaya dan ikut melakukan karena sudah sering melihat kejadian pelanggaran yang berujung pada terjadinya sanksi alam. Berbeda halnya dengan Informan DT sebagai anak dirinya mengaku pemilihan pasangan hdiup menurut pertimbangan suku Jawa dan mitosnya adalah hal yang negatif. Ia juga menyatakan bahwa lebih percaya pada kriteria atau peraturan-peraturan pemilihan pasangan dari agama seperti kutipan berikut "saya lebih mending percaya kriteria dari agama yang sudah jelas artinya dan maksudnya”.

b) Komunikasi yang Diterapkan Ibu Desa Gempol Dalam Pemilihan Pasangan Hidup

Komunikasi antar manusia memiliki tujuan salah satunya untuk memengaruhi penerima pesan. Maka dari itu dalam penelitian ini, komunikasi yang dilakukan oleh ibu bertujuan untuk memengaruhi dan mengubah sikap anaknya dalam memilih pasangan hidup. Hal ini dikarenakan berkaitan dengan mempertahankan budaya pemilihan pasangan hidup pada Suku Jawa khususnya di Desa Gempol. Selain itu, Tetapi setiap orang mempunyai cara sendiri-sendiri dalam memengaruhi lawan bicaranya.

Informan M dan SR memilih memberi pengarahan kepada anaknya. Mereka mengaku ketika anaknya sudah mulai bekerja mereka lebih intens memberi pengarahan mengenai pemilihan pasangan hidup. Setelah memberi pengarahan kemudian mencoba mengobrol mencari tahu perasaan sang anak kepada pilihannya dan memberi masukan. Informan SS lebih memilih menceritakan contoh-contoh nyata mengenai pemilihan pasangan hidup kepada anaknya. Sedangkan cara Informan S dan J yaitu dengan mengontrol secara ketat pertemanan anaknya. Bahkan tidak diperbolehkan menjalin hubungan pacaran.

\section{B. Pembahasan}

Berdasarkan analisis data yang telah dipaparkan di atas, untuk menghasilkan pembahasan maka peneliti juga akan menggunakan teori-teori yang ada di tinjauan pustaka sebagai penunjang. Teori teori tersebut dapat membantu peneliti untuk mengetahui bagaimana pola komunikasi ibu kepada anak perempuan Suku Jawa dalam pemilihan pasangan hidup. 


\section{Ibu dan Anak Perempuan Suku Jawa Terhadap Pemilihan Pasangan Hidup}

Menurut (Mardiyana, 2017) Ibu perlu menyediakan waktu bukan saja untuk selalu bersama tetapi untuk selalu berinteraksi maupun berkomunikasi secara terbuka dengan anaknya. Anak kemudian akan mengambil nilai-nilai sikap maupun perilaku ibu. Dari sini jelas bahwa perkembangan kepribadian anak bermula dari keluarga, dengan cara mengambil nilai-nilai yang ditanamkan orang tua secara sadar maupun tidak sadar. Seringkali kita melihat banyak orang tua yang menasehati anaknya dengan cara yang salah atau mereka tidak memberikan contoh yang sesuai. Hal ini mengakibatkan anak tidak sepenuhnya mengambil nilai atau norma yang ditanamkan. Salah satunya mengenai pemilihan pasangan hidup dalam Suku Jawa.

Berdasarkan analisis data dapat disimpulkan bahwa dalam pemilihan pasangan hidup ibu memiliki harapan yang besar agar anaknya mematuhi dan mempertahankan kebiasaan Suku Jawa di Desa Gempol. Sedangkan anak pada suku Jawa akan cenderung manut (menurut) atau mengikuti arahan dan nasehat ibu. Kelima informan ibu dan anak perempuan dewasa awal di Desa Gempol memiliki tingkat kepercayaan yang sama terhadap pemilihan pasangan hidup sesuai adat dan mitos suku Jawa. Tingkat kepercayaan mereka berada pada tingkat percaya tidak percaya yakni ada keraguan dengan adanya larangan ataupun sanksi. Tetapi mereka berupaya untuk tetap percaya serta mengontrol, mengarahkan dan selalu mengingatkan anak mereka untuk mematuhi adat suku Jawa.

Khususnya pada kebiasaan Suku Jawa di Desa Gempol dalam pemilihan pasangan hidup terdapat beberapa faktor yakni asal suku yang sama, memperhatikan bibit, bebet, bobot, memperhitungkan mengenai perhitungan hari kelahiran (weton), arah rumah dan tidak boleh melanggar mitos desa yakni Gempol - Gadung. Ibu juga berusaha agar anak mereka menganggap pemilihan pasangan hidup sesuai adat suku Jawa ini hal yang positif karena untuk menghindari adanya sanksi akibat melanggar adat suku Jawa yang ada.

\section{Pola Komunikasi Ibu dan Anak Perempuan Suku Jawa Terhadap} Pemilihan Pasangan Hidup

Pada penelitian ibu dan anak perempuan Suku Jawa dengan studi kasus Desa Gempol terhadap pemilihan pasangan hidup, peneliti menggunakan pola komunikasi model Braumrind. Dikarenakan dalam model tersebut membagi tiga jenis pola komunikasi orang tua dengan anak yakni Authoritarian, Permissive, dan Authoritative (Yusuf, 2001). Ketiga pola komunikasi tersebut menjelaskan cara berkomunikasi keluarga dengan indikator yang berbeda-beda, sehingga pola komunikasi ibu dengan anak perempuan suku Jawa dalam pemilihan pasangan hidup dapat dianalisis menggunakan model ini.

Pola komunikasi adalah model dari proses komunikasi, sehingga dengan adanya berbagai macam model komunikasi dan bagian dari proses komunikasi 
akan dapat dilihat pola yang mudah digunakan dalam proses komunikasi. Komunikasi antar pribadi melakukan proses persuasi untuk mengubah keyakinan, perasaan, pikiran dan juga tindakan dari penerima pesan. Pada penelitian ini, ibu di Suku Jawa berusaha mempersuasi anaknya agar mempertahankan adat budaya Suku Jawa dan mengikuti kebiasaan Desa Gempol dalam pemilihan pasangan hidup, tentunya cara mereka berbeda-beda pada masing-masing informan.

Peneliti telah mewawancarai lima pasangan ibu dan anak yang berbedabeda pendapat dan hanya dua pola komunikasi yang cenderung digunakan oleh lima pasangan tersebut. Peneliti melihat pola komunikasi yang digunakan ibu kepada anaknya berdasarkan beberapa faktor yakni dari bagaimana ibu memaksakan kehendaknya, bagaimana ibu mendengarkan pendapat anak dan bagaimana ibu memberikan penghukuman kepada anak. Selain itu, peneliti juga melihat dari peran ibu bagaimana ia mengawasai dan menerima keluh kesah anak. Kemudian dalam pemilihan pasangan hidup peneliti juga melihat bagaimana komunikasi yang diterapkan ibu. Berikut hasil analisa dari penelitian ini:

\section{a) Pola Komunikasi Authoritative (demokrasi).}

Pola komunikasi Authoritative atau demokratis memiliki arus komunikasi yang bersifat sirkuler sehingga arus komunikasi antara komunikan dan komunikator terjadi dua arah dan kedudukannya setara atau seimbang. Artinya pada penelitian ini, ibu dan anak perempuan dewasa awal memiliki kesempatan untuk menjadi komunikator maupun komunikan.

Peneliti menyimpulkan ketiga pasang informan yakni Informan M, J, dan SR menganut pola komunikasi Authoritative. Tetapi, tidak sepenuhnya mereka memenuhi indikator yang telah dijelaskan di tinjauan pustaka. Terkadang mereka juga kurang mengawasi serta memberikan perhatian penuh kepada anak. Pola komunikasi ini dianggap pola pengasuhan yang tepat untuk orang tua dan anak. Penerimaan dan kontrol terhadap anak tinggi, namun mereka memenuhi kebutuhan anak dengan baik dan memberikan keleluasaan anak untuk berpendapat. Pola komunikasi ini dapat menghasilkan anak yang percaya diri dengan konsep diri yang positif dan memiliki sikap terbuka.

Berdasarkan hasil wawancara yang dilakukan peneliti kepada ibu dan kroscek yang dilakukan kepada anak perempuan dewasa awal menunjukkan bahwa Informan M, J, dan SR. Ternyata berhasil memengaruhi anaknya untuk mempertahankan dan mengikuti pertimbangan budaya Suku Jawa serta kebiasaan pemilihan pasangan hidup pada Desa Gempol.

\section{b) Pola Komunikasi Authoritatian (Otoriter)}

Pola komunikasi Authoritarian atau otoriter merupakan pola komunikasi yang kurang sehat dalam hubungan ibu dan anak. Hal ini dikarenakan arus komunikasi dalam pola komunikasi otoriter ialah satu arah. 
Dimana sebagai komunikator, ibu tidak memberikan kesempatan komunikan untuk menyampaikan pendapat, memberikan kontrol yang tinggi dan memaksakan kehendak. Pada penelitian ini, meskipun kelima informan ibu mengaku mereka dapat mendengarkan pendapat anak, tetapi mereka secara bersamaan juga memaksakan kehendak mereka kepada anak. Mereka berpendapat bahwa seorang anak harusnya menurut kepada orang tua.

Peneliti menyimpulkan Informan S dan SS termasuk dalam pola komunikasi Authoritarian atau otoriter kepada anak perempuannya. Terkadang mereka juga kurang mengontrol anak dan emosional dikarenakan mereka memiliki kesibukan tersendiri, akibatnya anak mereka memilih menjauh. Hal ini juga dibuktikan dengan pernyaraan Informan FRA dan DT yang tidak bisa terbuka dengan ibunya. Keduanya merasa ibu mereka bukan orang yang nyaman untuk di ajak berdiskusi dalam penyelesaian masalah mereka.

Ketika mereka melakukan kesalahan mereka akan mendapat omelan, bentakan dan pernah mendapatkan hukuman fisik. Mereka tidak mendapatkan arahan yang baik ketika melakukan kesalahan. Kontrol yang mereka dapat juga tinggi dalam kehidupan sehari-hari. Hal ini menjadikan anak menjadi pembangkan dan tertutup. Khususnya dalam proses pemilihan pasangan hidup mengakibatkan ibu dan anak memiliki pandangan dan pertimbangan yang tidak senada.

\section{Teori Dialogis Hubungan Pada Ibu dan Anak Perempuan Suku Jawa Terhadap Pemilihan Pasangan Hidup}

Gagasan tentang hubungan sebagai proses dialektis dan dialogis ini didasarkan pada langkah besar dalam karya Mikhail Bakhtin Dunia sehari-hari ini merupakan salah satu kegiatan dan kreatifitas konstan serta juga titik awal untuk segala macam perubahan. Perubahan ini terjadi sangat lambat, begitu lambat hingga tidak dapat terjadi tindakan, tetapi hal ini merupakan bidang adanya keputusan-keputusan penting dibuat.

Dalam teori ini juga dijelaskan mengenai dua jenis kekuatan umum yang dapat memengaruhi kehidupan sehari-hari yakni sentipetal dan sentrifungal. Kekuatan sentripetal berupaya memberikan perintah dan kekuatan sentrifungal berupaya mengganggu perintah tersebut. Pada akhirnya akan menghasilkan perubahan dalam susunan kehidupan sehari-hari dengan makna baru. Sehingga bahasa dapat dikatakan sebagai media bagi kekuatan sentripetal dan sentrifungal.

Pada penerapan teori dialogis hubungan pada ibu dan anak perempuan suku Jawa di Desa Gempol, peneliti menyimpulkan mendengarkan pendapat anak dengan baik dan menggunakan bahasa yang nyaman dengan anak, akan semakin membangun keterbukaan dalam hubungan komunikasi ibu dengan anak. Kedekatan dan keterbukaan menjadikan mereka tidak memiliki keengganan untuk saling merespon, menilai dan memulai ucapan dengan 
ibunya. Karena sesuai dengan teori dialogis hubungan, sebagai pembicara ibu dituntut untuk menyesuaikan komunikasinya dengan anak dan sebaiknya anak juga ikut serta dengan merespons, menilai, dan memulai ucapannya.

Pada kelima pasangan informan ibu dan anak dalam penelitian ini, mereka diibaratkan memiliki kekuatan sentripetal dan sentrifungal. Dengan adanya dua kekuatan ini masing-masing pasangan akan menimbulkan makna baru mengenai pertimbangan pemilihan pasangan hidup. Dimana ibu memiliki kekuatan untuk memberikan perintah untuk mengikuti dan mempertahankan budaya serta kebiasaan Jawa Desa Gempol dalam pemilihan pasangan hidup. Sedangkan anak memiliki kekuatan sentrifungal untuk merespon, menilai dan memulai ucapan dengan ibunya, bahkan menerima atau menolak perintah untuk mengikuti atau tidak.

\section{Kesimpulan}

Berdasarkan penelitian yang telah dilakukan terhadap ibu dan anak perempuan dewasa awal Suku Jawa dalam pemilihan pasangan hidup sesuai dengan kebiasaan Desa Gempol, dapat disimpulkan bahwa terdapat persamaan dari kelima informan ibu yang telah diwawancarai oleh penulis, yakni merupakan ibu rumah tangga. Pola komunikasi yang diterapkan oleh tiga pasang ibu dengan anak perempuan dewasa awal dalam pemilihan pasangan hidup adalah Authoritative atau demokratis, sedangkan dua pasang ibu menggunakan pola komunikasi Authoritation atau otoriter. Namun kelima informan ibu memiliki kesamaan untuk memaksakan kehendak dengan kontrol yang tinggi, khususnya pada pemilihan pasangan hidup. Anak cenderung memiliki sifat manut atau menuruti perintah ibu, karena menganggap lebih berpengalaman dan demi mendapat restu.

Sesuai dengan teori dialogis hubungan, sebagai pembicara ibu dituntut untuk menyesuaikan komunikasinya dengan anak. Upaya penyesuaian tersebut dapat dilakukan dengan cara pendekatan, mendengarkan pendapat anak dengan baik dan menggunakan bahasa yang nyaman dengan anak. Pada kelima pasangan informan ibu dan anak perempuan dewasa awal, mereka diibaratkan memiliki kekuatan sentripetal dan sentrifungal untuk memerintah sedangkan salah satunya merespon, menilai dan memulai ucapan.

Kebiasaan ibu di Desa Gempol dalam pemilihan pasangan hidup mempertimbangkan beberapa faktor yakni asal suku yang sama, memperhatikan bibit, bebet, bobot, memperhitungkan mengenai perhitungan hari kelahiran (weton), arah rumah dan tidak boleh melanggar mitos desa yakni Gempol - Gadung. Walaupun mereka memiliki keraguan tetapi mereka berupaya untuk tetap percaya dan mempersuasi anak untuk mengikuti kebiasaan tersebut dengan memberi pengarahan dan mengontrol pertemanan anak. 


\section{BIBLIOGRAFI}

Anggriancy, Novely Roza. (2019). Resistensi Kaum Muda Dalam Mitos Larangan Pemilihan Jodoh (Studi Kasus di Desa Banaran Wetan, Kecamatan Bagor, Kabupaten Nganjuk). Repository Universitas Airlangga. Google Scholar

Candrasari, Yuli. (2012). Pola Komunikasi Keluarga Dan Pola Asuh Anak TKW. Jurnal Ilmu Komunikasi UPN Jatim, 2(2). Google Scholar

Devito, Joseph A. (2007). The Interpersonal Communication Book. USA: Pearson Education, Inc. Google Scholar

Djamarah, Syaiful Bahri. (2004). Pola Komunikasi Orangtua \& Anak Dalam Keluarga. Jakarta: Rineka Cipta. Google Scholar

Dyantika, Yunda, Wibowo, Judhi Hari, \& Ayodya, Beta Puspaning. (2018). Pola Komunikasi Antara Orangtua Dan Anak Perempuan Anggota Club Motor Cbr Di Mojokerto Pattern Of The Communication Between Parents And The Daughter As The Members of the Club Motor CBR in Mojokerto. Universitas 17 AGUSTUS 1945. Google Scholar

Endah, Kuswa. (2006). Petung, Prosesi, dan Sesaji dalam Ritual Manten Masyarakat Jawa. Kejawen : Jurnal Kebudayaan Jawa, 1(2). Google Scholar

Hellen Gabrellia Santoso, Heri Budianto. (2017). Pola Komunikasi Orang Tua Dalam Mendidik Anak di Keluarga Tionghoa (Studi Kasus Pada Keluarga Tionghoa di Kecamatan Tambora).

Juwito, \& Alamiah, Syifa Syarifah. (2012). Pola Komunikasi Politik Perempuan Dalam Pemilu. Jurnal Ilmu Komunikasi, 1(2). Google Scholar

Kominfo Nganjuk. (2019). Sejarah Desa Gempol.

Lastarya, Bintang Gia. (2018). Komunikasi Orang Tua Kepada Anak Mengenai Pemilihan Pasangan Terkait Bibit, Bebet, Dan Bobot Melalui Storytelling. Repository Universitas Airlangga. Google Scholar

Liliweri, Alo. (2015). Komunikasi Antar Personal. Jakarta: Kencana Prenada Media. Google Scholar

Mardiyana, Alfa. (2017). Peran Istri Dalam Pembentukan Keluarga Sakinah Menurut Al-Qur'an (Perspektif Tafsir Al-Misbah Dan Tafsir Al-Azhar) | Kontemplasi: Jurnal Ilmu-Ilmu Ushuluddin. Google Scholar

Moleong, Lexy J. (2014). Metode Penelitian Kualitatif. Bandung: PT. Remaja Rosdakarya. Google Scholar

Negara, Ais Abrar Chandra. (2016). Laporan Akhir Kuliah Kerja Nyata - Belajar 
Alfien Baddrin Afdhilla dan Syifa Syarifah Alamiyah

Bersama Masyarakat Ke-54 Universitas Airlangga Di Kelurahan Gempol Kecamatan Rejoso Kabupaten Nganjuk 2016. In Kementerian Riset Teknologi dan Pendidikan Tinggi Universitas Airlangga.

Ngalimun. (2018). Komunikasi Interpersonal. Yogyakarta: Pustaka Belajar. Google Scholar

Palianrungi, Andi. (2018). Pola Komunikasi Antara Ibu Dan Anak Dalam Membentuk Karakter Beribadah Anak.

Panorama, Dika Witdari Indra. (2019). Pola Komunikasi Ibu Dengan Anak Remaja Putri Untuk Mengatasi Perilaku Merokok Di Surabaya. UPN Veteran Jawa Timur.

Saraswati, Putri. (2011). Hubungan Antara Persepsi Anak Terhadap Peran Orang Tua Dalam Pemilihan Pasangan Hidup Dengan Kecenderungan Pemilihan Pasangan Hidup Berdasarkan Status Sosial Ekonomi Pada Dewasa Awal. Jurnal Psikologi, 6(1), 347-364. Google Scholar

Suciati. (2015). Komunikasi Interpersonal (Sebuah Tinjauan Psikologis dan Perspektif Islam). Yogyakarta: Buku Litera.

Sukmadinata, Nana Syaodih. (2016). Metode penelitian pendidikan. Bandung: PT Remaja Rosdakarya.

Sumardijati. (2012). Pola Komunikasi Antara Orangtua Dan Anak Dalam Keluarga Broken Home Di Surabaya | MSi | Jurnal Ilmu Komunikasi. Jurnal Ilmu Komunikasi UPN Jatim. Google Scholar

Yusuf, Syamsu L. (2001). Psikologi Perkembangan Anak dan Remaja. Bandung: PT Remaja Rosadakarya. Google Scholar

\section{Copyright holder:}

Alfien Baddrin Afdhilla dan Syifa Syarifah Alamiyah (2021)

First publication right:

Journal Syntax Literate

This article is licensed under:

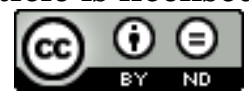

